\title{
Alternative Building Materials (ABM): Towards Adoption of Common Terminology and Definitions
}

\author{
Johnson Josiah MARUT ${ }^{1} \quad$ Natalia A. ANIGBOGU ${ }^{1}$ Maren Mallo DANIEL ${ }^{2}$ \\ 1.Department of Building, Faculty of Environmental Sciences, University of Jos, Nigeria \\ 2.Department of Estate Management, Faculty of Environmental Sciences University of Jos Nigeria
}

\begin{abstract}
There are differences in the definitions of Alternative Building Materials (ABM) and differences in the terminologies that are used in describing ABM by different researchers in the construction industry. ABM is a generic term, which is characterised of or relating to a class or group of building materials, not really specific. It encompasses building and construction materials that in literature are referred to by different names such as alternative materials, local building materials, unconventional building materials, alternative residential construction materials, sustainable building materials, indigenous building materials, vernacular building materials, green building materials, environmentally responsible building materials, eco-friendly building materials, etc. The research employed systematic literature review and content analysis to generate and analysedall the necessary information as the methodology. A working (operational) definition of Alternative Building Materials is being offered as building materials that are an alternative to conventional building materials in the form of total or partial substitution of the materials or its constituents for the purpose of reducing the cost, addressing environmental issues or dealing with lack of conventional materials. The characteristics of ABM have been identified to include low or no chemical emissions that can lead to poor indoor air quality, recycled content (post-consumer and preconsumer), no CFC, HCFC, or other ozone depleting substances content, low embodied energy, locally produced, possibility of repairs and replacements with local means and social acceptability amongst others. Some of the benefits of utilizing ABM include; low embodied energy (often leading to reduced greenhouse gas emissions), ease of construction, widespread availability and low cost.
\end{abstract}

Keywords: Alternative Building Materials, Definition, Adoption, Terminology, Characteristics

DOI: $10.7176 / \mathrm{CER} / 12-11-03$

Publication date: November $30^{\text {th }} 2020$

\section{Introduction}

There are divergent views onwhat constitute Alternative Building Materials (ABM) and how this could be defined (Anigbogu, 1999; Opoko, 2006; Joseph \& Tretsiakova-McNally, 2010; Danso, 2013). Some literatures (Opoko, 2006; United Nations Centre for Human Settlement (UNCHS) 2015; Mpakati-Gama, Wamuziri\& Sloan, 2012) classifies ABM as traditional materials or materials that are not modern or conventional in nature. This apparent lack of consensus on the concept of ABM creates a knowledge gap which this study seeks to fill. To this end, the research examines literature on $\mathrm{ABM}$ with a view to creating a common terminology and definition for the concept. This broad aim is pursued within the following three-folds: firstly, the study of the characterises ABM with the view to developing a nomenclature of terminology about the concept; secondly, it analyses wide range of definitions of ABMs that exist in literature with the view to providing a consensus definition that could guide built environment researchers and thirdly determining the benefits of utilising ABM.

\section{Methodology}

This research has employed literature review methodology with sources of data from journals, conference proceedings, reports, policy collected online and libraries based on systematic review and content analysis. It is very important for this study because it has provided an overview of areas in which the research is disparate. In addition, it is an excellent way of synthesizing research findings to show evidence on a meta level and to uncover areas in which more research is needed, which is a critical component of creating theoretical frameworks and building conceptual framework (Snyder, 2019). Systematic review is also for synthesizing both quantitative and qualitative studies (Okoli \& Schabram, 2017). Systematic reviews have foremost been developed as a way to synthesise research findings in a systematic, transparent, and reproducible way and have been referred to as the gold stand among reviews (Daviset, Mengersen, Bennett, \& Mazerolle, 2014). A systematic review can be explained as a research method and process for identifying and critically appraising relevant research, as well as for collecting and analysing data from said research (Liberati, Altman, Tetzlaff, Mulrow, Gøtzsche, Ioannidis, Moher, 2009). The aim of a systematic review is to identify all empirical evidence that fits the pre-specified inclusion criteria to answer a particular research question or hypothesis. By using explicit and systematic methods when reviewing articles and all available evidence (Snyder, 2019). Content analysis involves counting and comparisons, usually of key words or content, followed by the interpretation of the underlying context (Hsieh \&Shannon, 2014). Content analysis is a research tool used to determine the presence of certain words or concepts 
within texts or sets of texts (Colorado State University, 2020). Texts can be defined broadly as books, book chapters, essays, interviews, discussions, newspaper headlines and articles, historical documents, speeches, conversations, advertising, theater, informal conversation, or really any occurrence of communicative language.

\section{The Study}

The study is basically the areas that this study would discuss in order to achieved the aim and objectives of the research work, these include, characteristics of Alternative Building Materials, understanding the term Alternative Building Materials which include: definition of the term Alternative Building Materials; and terms that are used in describing Alternative Building Materials.

\subsection{Characteristics of Alternative Building Materials}

The basic attributes of ABM include recycled content, low embodied energy, natural materials, energy efficiency, non-toxic or less-toxic content, reusability and recyclability (Kim \& Rigdon, 1998). California Stormwater BMP Handbook (2003) observed that ABM should be selected instead of conventional materials for new building and renovation based on the characteristics that they possessed. Farahzadi (2014) in his research on eco-friendly building materials as ABM observed that the materials have the following characteristics: better indoor air quality, less embodied energy, low heat transmission, low carbon dioxide $\left(\mathrm{CO}_{2}\right)$ emissions, low volatile organic compounds (VOC) emissions and low toxic content. Farahzadi, Gutierrezi, Bakhtiari, Azemati and Hosseini (2016) observed that the idea of substituting conventionally used building materials with ABM which are environmentally friendly building materials is that the materials have satisfactory result in decreasing the functional (thermal) energy consumption of buildings by $9.5 \%$ and reduction in the carbon dioxide emissions by $3 \%$. Luis and Tormenta (1999) listed the following characteristics of ABM materials, which he refers to as high -performance building materials:

1. They have benefits on the building occupants in the following ways: (a) Low or no chemical emissions that can lead to poor indoor air quality; (b) Do not contain highly toxic compounds; (c) Are durable.

2. They are resource efficient in the following ways: (a) Have recycled content (post-consumer and pre-consumer); (b) Are easily re-used (whole or through disassembly); and (c) Are easily recycled (preferably in closed-loop recycling systems).

3. They have far-reaching, global impacts particularly the materials that:

(a) Contain no CFC, HCFC, or other ozone depleting substances; (b) Are obtained from sustainable harvesting practices; (c) Are obtained from local resources and manufacturers; (d) Have low embodied energy; (e) Are derived from renewable resources.

In their book “Appropriate Building Materials" Stulz and Mukerji (1993) list nine factors that determine the appropriateness of an Alternative Building Material:

(a) Locally produced; (b) Whether cheap, abundant and renewable or not; (c) Location of the production factory and the machines and equipment required; (d) Energy requirements for the production, and the amount of waste and pollution caused; (e) Climatic acceptability and appropriateness; (f) Safety against hazards; (g) Whether its technology can be easily transferred to the local workers; (h) Possibility of repairs and replacements with local means; (i) Social acceptability.

ABM are distinct as they are sustainable unlike the conventional building materials (Morela, Mesbaha, Oggerob \& Walker, 2001). ABM are generally lower in embodied energy and toxicity than man-made materials. They require less processing and are less damaging to the environment. Many, like wood, are theoretically renewable (Morela et al., 2001). When locally found building materials are incorporated into building products, the products become more sustainable (Kim \& Rigdon, 1998). Hema (2012) opined that ABM should be selected on the bases that they are found locally or regionally which will lead to reduction in transportation cost. As an example, Amazon (2001) revealed that straw-bales are healthy as they do not include paints, chemicals, glues or toxins; it is also an energy efficient recycled material that does not generate pollution. Straw is an end-product of food production and thus a resource that can easily be renewed (Snell \&Callahan, 2005). Mansour, Srebric and Burley (2007) stressed that burning rice straw causes health risks and severe pollution, which can be avoided by using rice straw in construction. In agreement Elsayed (2015) asserted that straw bale can be used as structural construction material and thermal insulation (very good insulative abilities, reduces thermal bridging) or acoustic absorption.

Building with ABM reduces the embodied energy of the building by $215 \%$ for the stone masonry and by $285 \%$ for the rammed earth walls and also by using local materials the amount of transported materials used in a project can be decreased substantially (Morela et al., 2001). Similarly, José, Paulina and António (2016) explained that clay mortars can be considered as ABM for indoor plastering since they can contribute to improving important aspects of building performance and sustainability. Apart from being products with low embodied energy they also significantly contribute to the health and comfort of inhabitants. Therefore, earth-based plasters may also passively promote the energy efficiency of buildings, since they contribute to decreasing the needs of mechanical 
ventilation and air conditioning (José et al., 2016). UN-HABITAT (2012) revealed that compressed earth blocks have higher and thinner walls with better compressive strength and water resistance. Advantages of compressed earth blocks when compared to fired bricks include 70 percent higher energy efficiency; 20-40 percent economic savings; and savings of fire wood. Other good qualities include the ability for local production; flexible sizing; labour intensiveness that can create jobs; good stability and strength (can be improved by using high density and high percentage of stabilisers); thermal insulation; regular shape and size; easy transportation; good earthquake resistance, typhoon, rain and insect resistance; and suitability for all climates except very wet climates (UNHABITAT, 2012).

\subsection{Understanding the Term Alternative Building Materials}

The understanding of the term Alternative Building Materials (ABM) is developed from three basic point of independent but interrelated perspectives; the first is the need to understand what ABM are, secondly, the need to identify the different terms that are used in describing ABM and thirdly, the need to establish the basic features (characteristics) of ABM which has been discussed above. Presently, there is little or no agreement on what constitutes ABM. Understanding what ABM are is a key towards their utilisation in the building construction industry as seen in figure 1 .

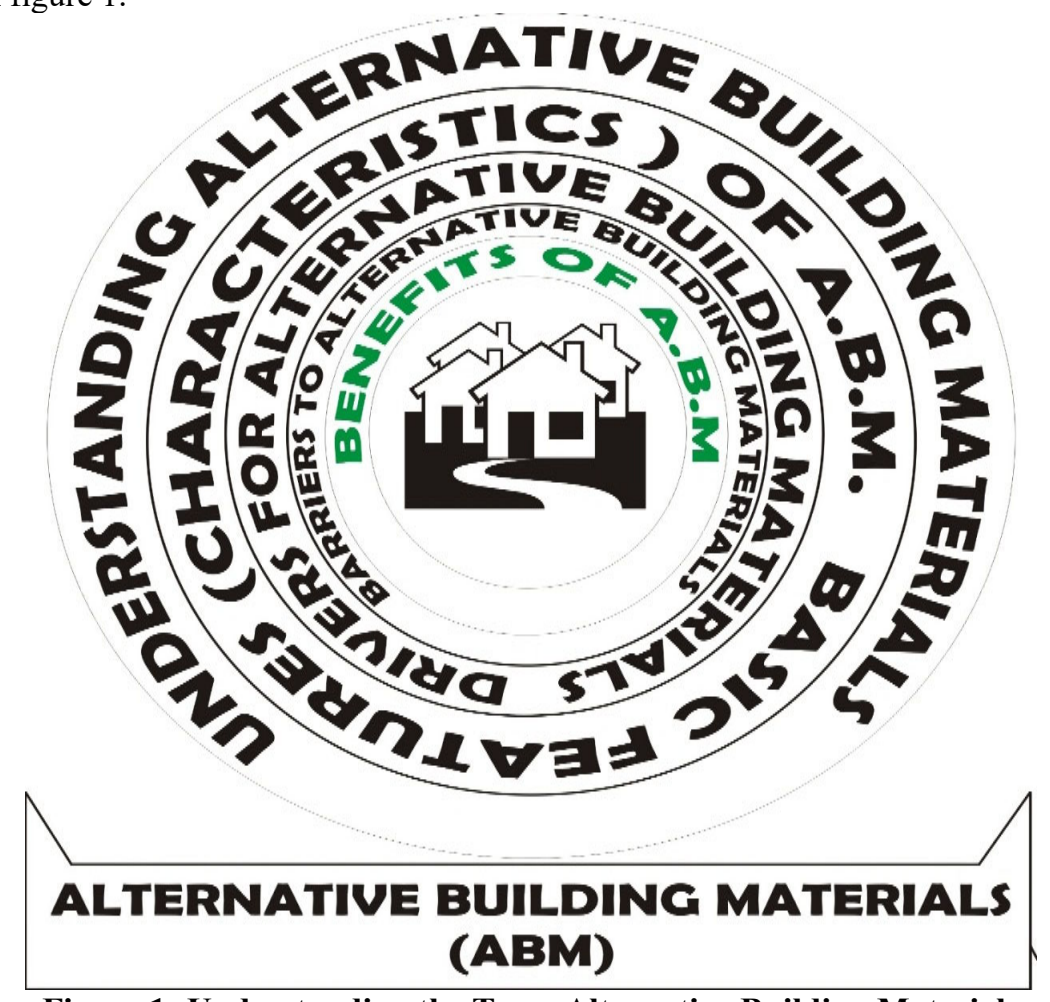

Figure 1: Understanding the Term Alternative Building Materials

\subsubsection{Definition of the Term Alternative Building Materials}

Researchers in the field of building materials have come up with various definitions of ABM (Vidya\&Radha, 2019). Authors used different terms to describe ABM including alternative materials, local building materials, unconventional building materials, alternative residential construction materials, sustainable building materials, indigenous building materials, vernacular building materials, green building materials, environmentally responsible building materials, eco-friendly building materials, rapidly renewable or harvested building materials, recycled building materials, e.t.c. (Anigbogu, 1999; Brian, 2001; Djokoto, Dadzie\&Ohemeng-Ababio, 2014; JongJin, K., \& Brenda, R. 2008; John \& Tinker, 1998; Sheth, 2016; Alrashed, Asif \&Burek, 2017). Anigbogu (1999) defined ABM as conventional building materials that are being modified so as to reduce the cost of production, or unconventional (traditional, local, indigenous, vernacular) building materials that are modified so as to incorporate them into present day building works. Milani (2005) defined ABM as the intelligent use of local materials, both natural materials (rammed earth, cob construction and straw bale) and unorthodox resources provided by the waste stream (tires and cans). Alternative Building Materials can be defined as materials other than cement blocks or clay bricks that can offer similar or superior quality housing (Windapo \& Goulding, 2013).Ross (2006) defined $\mathrm{ABM}$ as either: non-traditional building materials; or, materials that are derived from recycling or industrial end products.

Opoko (2006) defined Alternative Building Materials as building materials manufactured or assembled in the country as opposed to imported materials which come into the country in their finished form; these materials 
evolved from locally available materials in the country through research and development (R \& D). The term ABM is usually used to refer to materials that are not highly industrialised, or materials that do not have standards and methods that are used in the current construction practice, which include local building materials, indigenous building materials, vernacular building materials and traditional building materials (El-Kabbany, 2013).Joseph and Tretsiakova-McNally (2010) defined ABM as those building materials that have a range of beneficial properties such as low toxicity, durability, low level of Green House Gases (GHG) and other pollutants emissions, high recycle potential and minimal processing requirements; many of them are environmental-friendly and do not produce hazardous end products. Załęcka-Myszkiewicz (2013) defined ABM as those materials which are present in building engineering which take advantage of natural structures with the use of local materials available and accessible on the construction site or its vicinity. Madhusudanan and Amirtham (2015) defined ABM as those industrial and agricultural products that can be used to replace conventional building materials. Similarly, Constructor (2017) defined ABM as those building materials which can be used by replacing the conventional building materials. These materials are made from end products and thus are minimising environmental pollutions. Examples of these materials include: aluminum, bitumen materials, soil conditioning agents, tempered glass, crumb rubber, fiber reinforced polymer, glass fiber reinforced plastics, bamboo, reinforced plastics, ferro-cement and polyester fibers (Constructor, 2017). Chanlers (2018) defined ABM as products that have been developed with environmental issues in mind, helping to reduce the large amount of carbon dioxide $\left(\mathrm{CO}_{2}\right)$ gasses that are produced by the construction industry. It is important to understand that ABM is a generic term, which is characterised of or relating to a class or group of building materials, not really specific, it encompasses building and construction materials that in literature are referred to by different names.

Consequently upon these definitions, Alternative Building Materials can be defined as building materials that constitute an alternative to conventional building materials in the form of total or partial substitution of the conventional materials or its constituents for the purpose of reducing the cost, addressing environmental issues or dealing with lack of conventional materials. Terms that are used by different authors to described ABM are shown in (Table 1).

\section{Table 1}

\subsubsection{Terms that are Used in Describing ABM} S/N Terms Used in Describing ABM

Authors and Year

1. Alternative Construction Materials (ACM) (Anigbogu, 1999)

2. Alternative Materials

3. Local Building Materials

4. Unconventional Building Materials

(Brian, 2001; Nweke, 2017)

(Opoko, 2006; Matawal, 2011; Mukiibi, 2015)

5. Alternative Residential Construction Materials (Stroh, 2001)

6. Sustainable Building Materials

(Joseph \&Tretsiakova-McNally, 2010, Danso, 2013)

(Laura, Daniel \& Javier, 2010; Shandalovich, Hawkins, LöktasandPutelis, 2012; Djokoto, Dadzie\&Ohemeng-Ababio, 2014)

7. Indigenous building materials

8. Vernacular Building Materials

(Fien, Charlesworth, Lee, Morris, Baker \& Grice, 2008)

9. Green Building Materials

10. Environmental Building Materials

11 Healthy Building Materials

12 Recycled Building Materials

13 High Performance Building Materials

14 Environmentally Responsible Building(Farahzadi, Gutierrezi, Bakhtiari, Azemati\& Hosseini, 2016) Materials

15 Rapidly Renewable or Harvested Building(Amazon nails, 2001; Fithian \& Sheets, 2014; Sheth, 2016) Materials

16 Eco-friendly Building Materials

17 Low Embodied Energy Building Materials

18 Eco-Building Materials

19 Traditional Building Materials

(Alrashed, Asif \&Burek, 2017).

(Brian 2001; Woolley, 2006; Darren, 2007; Hema, 2012; Cai\& Sun, 2014)

(Fithian \& Sheets, 2014)

(Amazon nails, 2001; Cai\& Sun, 2014)

(Kim \&Rigdon, 1998; Sheth, 2016; John \& Tinker, 1998; Sheth, 2016)

(Luis \&Tormenta, 1999)

\section{Benefits of Utilising Alternative Building Materials}

The use of Alternative Building Materials (ABM) aims to promote locally (natural) available resources and to enhance the inefficient consumption of the natural resources and the protection of excessive use of such resources on which most of the low income communities rely in most developing as well as developed countries. The use of 
ABM is also considered as a way of curbing the environmental impacts attributed to the building sector (MpakatiGama, Wamuziri\& Sloan, 2012). Magutu (2015) emphasied that Alternative Building Materials are quite economical, durable, sanitary and safe in construction. The essence of ABM is to address and solve socio-economic problems such as unemployment, shortage of residential spaces while ensuring economic feasibility (Madhusudanan\&Amirtham, 2015; Gbadebo, 2014). The major benefits of ABM over conventional materials typically include; a low embodied energy (often leading to reduced greenhouse gas emissions), ease of construction, widespread availability and low cost (Vercillo, 2011). Development of Alternative Building Materials has a number of economic, environmental and health benefits. It reduces the house production costs, which is a very important aspect for the successful access to decent housing by low-income earners as well as those that are well to do in the society; it protects the eco-system, and it contributes to the improvement of the living environment of a given community through the prudent use of local resources (Moreal et al., 2001).

In their research on the benefits of utilising wood over concrete as Alternative Building Material, Ede, Adebayo, Bamigboye and Ogundeji (2015) explained that the lighter weight of timber structure entails a smaller foundation and therefore economic benefit, particularly where sub-soil conditions are poor and prone to differential movements. Nweke (2017) identified structural insulated panels as one of the Alternative Building Material which have the benefits of the walls to be erected quickly, usually within hours, compared to about two weeks for traditional stick (lumber) framing. Insulation is installed in a controlled environment and is measured to fit precisely, the house built using this material is likely to be airtight in comparison with a conventionally built home, which is an energy-efficiency plus (Nweke, 2017). Interlocking blocks as an ABM to conventional blocks offer several benefits such as design flexibility, cost effectiveness, reduced construction time, environmental friendliness and solution to space shortage, desirable qualities and thermal properties (Adedeji\& Fa, 2012; Job \&Afunanya, 2016).

From another point of view, the essence of ABM is to address and solve socio-economic problems such as unemployment, shortage of residential accommodation while ensuring economic feasibility with materials such as, fly ash, copper slag and phosphogypsum slag and rice husk ash to mention but a few, protection of biodiversity which help to reduce waste systems and restore natural resources (Madhusudanan\&Amirtham, 2015; Chandlers, 2018). Bernard (2017) highlighted some of the benefits of ABM to include: construction costs typically much lower than the conventional building materials, walls absorb sound and serve as a "thermal mass," which keeps the indoor temperature stable by heating up during the day and then slowly releasing the heat throughout the evening. Locally produced building materials shortens transport distances, thus reducing air pollution produced by vehicles. Often, local materials are suited to climatic conditions, and their purchases support area economies (JongJin\& Brenda, 1998). Alternative Building Materials can help in: energy conservation alternative; minimise the use of high energy materials; conservation of the environment, environment-friendly technologies; minimise transportation and maximise the use of local materials and resources; decentralised production and maximum use of local skills (Venkatarama, 2004).

\section{Conclusion}

Researchers in the building construction materials industry have divergent views of the concept of Alternative Building Materials (ABM) as well as the definition of the term. Various definitions of the term Alternative Building Materials (ABM) have been suggested by the various researchers in the building construction materials industry however, this researcher has adapted the definition of ABM as building materials that are an alternative to conventional building materials in the form of total or partial substitution of the materials or its constituents for the purpose of reducing the cost, addressing environmental issues or dealing with lack of conventional materials. This definition is all encompassing as it comprises of most of the suggested definition by various researchers in the construction industry. Various characteristics of ABM have also been discussed. The benefits of utilising the materials have also been highlighted. The research therefore, recommends the adoption of this definition of the $\mathrm{ABM}$ and the characteristics of the materials towards the utilisation of the materials in the construction.

\section{Reference}

Amazon nails (2001). Information guide to straw bale building, for self-builders and the construction industry. Retrieved from: http://www.baubiologieat/dow

Anigbogu, N. A. (1999). Economics of alternative construction materials: Some conceptual issues. Nigerian Journal of Construction Technology Management, 2(1) 93-96.

Bernard, M. (2017). Straw, Cobs, and Rammed Earth: Alternative Building Materials. The spruce. Retrieved from https://www.thespruce.com/murrye-bernard-1820959

Brian, M. (2001). Building materials in green economy community-based strategies for dematerialisation. Paper delivered to the biennial conference of the Canadian Society for Ecological Economics (CANSEE), McGill University, and Montreal. Retrieved from http://greeneconomics.net/index.ht $\mathrm{ml}$

Chanlers, C. (2018). Alternative building materials. Retrieved from https://chandlersbs.co.uk/ 
Colorado State University (2020). An Introduction to content analysis. Retrieved from http://writing.colostate.edu

Danso, H. (2013). Building houses with locally available materials in Ghana: Benefits and Problems. International Journal of Science and Technology 2 (2), 225-231. Retrieved from: http://www.journalofsciencestechnology.org/

Davis, J., Mengersen, K., Bennett, S., \& Mazerolle, L. (2014). Viewing systematic reviews and meta-analysis in social research through different lenses. Springer Plus, 3, 511. Retrieved from https://doi.org/10.1186/21931801-3-511.

Djokoto, S. D., Dadzie, J., \&Ohemeng-Ababio, E. (2014). Barriers to sustainable construction in the Ghanaian construction industry: consultants' perspectives. Journal of Sustainable Development, 7 (1), 134-143. doi: $10.5539 /$ jsd. v7n1p 13

Ede, A. N., Adebayo, S. O., Bamigboye, G. O., \& Ogundeji, J. (2015). Structural, Economic and Environmental Study of Concrete and Timber as Structural Members for Residential Buildings in Nigeria. The International Journal of Engineering and Science, 4 (3), 76-84. Retrieved from www.theijes.com

El-Kabbany, M. F. (2013). Alternative building materials and components for affordable housing in Egypt towards improved competitiveness of modern earth construction. A Thesis submitted for the Requirement of the Degree of Master of Science in Integrated Urbanism and Sustainable Design. Retrieved from https://www.escodido.org/Data/nf

Elsayed, M.S.G. (2015). Straw bale is future house building material, Egypt. Retrieved from: http:// www.urbanharmony.org/en/download/research/

Farahzadi, L. (2014). Designing a condominium in Tehran with ecological perspective by using eco-friendly materials. M.A. Thesis, Engineering Faculty, Science \& Research Branch of Islamic Azad University, Iran. In Persian.

Farahzadi, L., Gutierrezi, R. U., Bakhtiari, A. R., Azemati, H., \& Hosseini, S. B. (2016). Assessment of alternative building materials in the exterior walls for reduction of operational energy and $\mathrm{CO}_{2}$ emissions (Case study: A typical residential building in Tehran). International Journal of Engineering and Advanced Technology, 5 (5), 183-189. Retrieved from https://www.researc0

Fien, J., Charlesworth, E., Lee, G., Morris, D., Baker, D., Grice, T. (2008). Towards a design framework for remote Indigenous housing. Australian Housing and Urban Research Institute RMIT-NATSEM Research Centre. Retrieved from: www.ahuri.edu.au

Hema, C. (2012). Green techniques in building construction (concept). International Journal of Biotech Trends and Technology (IJBTT) 2 Issue 2 (1), 26-36. Retrieved from: http://www.ijbttjournal.org

Hsieh, H., \&Shannon, S. E. (2014). Three Approaches toQualitative Content Analysis. Research Gate. Retrieved from https://www.researchgate.net7

Jannik, G., \& John, R. B. (2015). Construction sector views on low carbon building materials. Building Research \& Information, 44 (4). Retrieved from http://dx.doi.org/10.1080/02

Job, O. F., \& Afunanya, J.E. (2016). Innovation in material production and utilization in the building industry. Proceeding of the $46^{\text {th }}$ Buildings' Conference/Annual General Meeting Edo 2016, 23-32.

Job, O.F., Pam, M., \&Ishaya, A. A. (2018). Physical and thermal properties of rice husk ash blended high strength concrete at elevated temperature. International journal of modern trends in engineering and research, 122133. doi:10.21884/IJMTER.2017.4

John, V. M. \& Tinker, J. A. (1998). Recycling waste as building materials: An Internet Database.http://www.irbnet.de/daten/iconda/CIB8640.pdf

Jong-Jin, K., \& Brenda, R. (2008). Sustainable architecture module: Qualities, Use, and Examples of sustainable building materials. Retrieved fromwww.umich.edu/ nppb/

José, L., Paulina, F. \& António, S. S. (2016). Earthen plasters based on Illitic Soils from Barrocal region of Algarve: Contributions for building performance and sustainability. Engineering Materials, 678. 64-77. doi: 10.4028/www.scientific.

Joseph, P. \& Tretsiakova-McNally, S. (2010). Sustainable Non-Metallic Building Materials. Sustainability, 2, 400427. doi: $10.3390 / \mathrm{su} 2020400$

Laura, F., Daniel, C., \& Javier, I. (2010). Impact of sustainability perceptions on optimal material selection in construction projects. Coventry University and the University of Wisconsin Milwaukee central for byproducts utilisation, second international conference on sustainable construction materials and technologies. Retrieved from http://www.claisse.info/proceedings.htm

Liberati, A., Altman, D.G., Tetzlaff, J., Mulrow, C., Gøtzsche, P.C., Ioannidis, J.P.A. Moher, D.(2009). The PRISMA statement for reporting systematic reviews and meta-analyses of studies that evaluate healthcare interventions: Explanation and elaboration. Annals of Internal Medicine, 151, 65. Retrieved from https://doi.org/10.7326/0003-4819-151-4-200908180-00136.

Luis M., \& Tormenta, P.E. (1999). High performance building guidelines. City of New York Department of Design and Construction. Retrieved from https://www1.nyc.gov 
Madhusudanan, S., \&Amirtham, L. R. (2015). Alternative building material using industrial and agricultural wastes. Key Engineering Materials, 650, 1-12. doi: 10.4028/www.sci

Magutu, J. (2015). Towards populisation of low cost building materials and technologies for urban housing in developing countries. International Journal of Scientific Research and Innovative Technology, 2 (1), 20-43.

Mansour, A., Srebric, J., \& Burley, B. J. (2007). Development of straw-cement composite sustainable building materials for law-cost housing in Egypt. Journal of Applied Sciences Research, 3(11): 1571-1580.

Matawal, D. S. (2011). Linking academia to industry: a case study of the building and construction industry. Director-General/Chief Executive Officer Nigerian Building and Road Research Institute, NBRRI. Retrieved from: http://www.notap.gov.ng

Milani, B. (2005). Building materials in green economy community-based strategies for dematerialisation. Paper delivered to the biennial conference of the Canadian Society for Ecological Economics (CANSEE), McGill University, and Montreal. Retrieved from: http://greeneconomics.net/indel

Moreal, J.C., Mesbah, A., Oggero, M., \& Walker, P. (2001). Building houses with local materials means to drastically reduce the environmental impact of construction. Building and Environment..36 (10) 1119-1126.

Moreal, J.C., Mesbah, A., Oggero, M., \& Walker, P. (2001). Building houses with local materials means to drastically reduce the environmental impact of construction. Building and Environment, 36 (10) 1119-1126.

Mottaeva, A.., Zheltenkov, A., Stukanova, I., Ryabichenko, S., \&Zhuk, S. (2016). Innovative development of building materials industry of the region based on the cluster approach. MATEC Web of Conferences 7, 07026. doi: 10.1051/matecconf/20167307026

Mpakati-Gama, E. C., Wamuziri, S. C., \& Sloan, B. (2012). The Use of alternative building materials in developing countries: Addressing Challenges Faced by Stakeholders. Retrieved from: Https:/Www.Researchgate.Net/Publica

Mrema, G.C. (2011). Rural structures in the tropics: Design and Development. Wageningen University and Research Library Catalogue. Retrieved from http://edepot.wur.nl/2186

Mukiibi, S. (2015). The potential of local building materials in the development of low cost housing in Uganda. International Journal of Training and Development, 2 (1), 84-92. Retrieved from http://www.technoscience.se//

Nweke, M. (2017). Alternative building materials panacea to soaring construction cost. The sun newspaper of Nigeria of $17^{\text {th }}$ December. Retrieved from http://sunnewsonline.co/

Okoli, C., \& Schabram, K. (2017). A Guide to conducting a systematic literature review of information systems research. Retrieved from http://chitu.okoli.org

Opoko, A.P. (2006). Prospects and challenges of local building materials development and use in Nigeria. The Professional Builder. Journal of the Nigerian Institute of Building, 13-17.

Pitt, M., Tucker, M., R., Mike, L., \& Jennifer, (2009). Towards sustainable construction: promotion and best practices. Construction Innovation. 9, 201-224.

Ross, P. (2006). Best practice guidelines for the use of alternative materials and processes in road construction with respect to environmental issues final report. Retrieved from www.nzta.govt.nz/...use.../guide.pdf

Sheth, K. N. (2016). Sustainable building materials used in green buildings. 9th International Conference on Engineering and Business Education \& 6th International Conference on Innovation and Entrepreneurship, 135-143. Retrieved from https://www.researchga

Snell, C., \& Callahan, T. (2005). Building green: A complete how-to guide to alternative building: earth plaster, straw bale, cordwood, cob, living roofs. New York: Lark Books. Retrieved from https://www.amazon.de//en/Clarke-

Snyder, H. (2019). Literature review as a research methodology: An overview and guidelines. Journal of Business Research 104, 333-339. Retrieved from https://doi.org/10.1016/j.jbusres.2019.07.039

Stulz, R., \& Mukerji, K. (1993). Appropriate Building Materials, a catalogue potential solutions.3rd ed. Practical Action Publishing. Retrieved from http://madeingr

The Constructor (2017). Alternative building materials used in the construction industry. Civil Engineering Homes. Retrieved from https://theconstructor.org/

Umezinwa, C. (2004). Alternative building materials, acceptability and usage problems. A BSc. Thesis Submitted to the Department of Building, University Jos

UN-HABITAT (2012). Going green: A handbook of sustainable housing practices in developing Countries. United Nations Human Settlements Programme (UN-Habitat) Nairobi GPO Kenya. Retrieved from: http://www.lavoutenubienng

United Nations Centre for Human Settlement (2015). Building materials for housing: Report of the Executive Director, United Nations Commission on Human Settlements. Habitat International, 17 (2), 1-20. Retrieved from https://www.un.org/ruleoflaw/un-and-the-ru

Venkatarama R. B. V. (2004). Sustainable building technologies, Special section: application of S\&T to rural areas. Current Science, 87 (7), 899-907. Retrieved from: http://www.iisc.ef 
Vercillo, K. (2011). History of alternative home building. Retrieved From https://kathrynvercillo.hubpages.com/ Vidya, A., \& Radha, A (2019). Alternative low-cost building materials. Retrieved https://www.scribd.com/document/408806248/Alternative-Low-Cost-Building-Material

Wells, J. (2003). Appropriate Building Technologies: An Appraisal based on Case Studies in Senegal and Kenya. Habitat International, 11 (3), 203-216.

Wells, J., Sinda, S. H., \& Haddar, F. (2008). Housing and building materials in low-income settlements in Dares Salaam. Habitat International, 22 (4), 397-409.

Windapo, A. O. \& Goulding, J. (2013). Value-based perspectives of stakeholders' building requirements in low cost and government subsidised housing projects in South Africa", Construction Innovation, 13 (4) 424 - 444. Retrieved from http://dx.doi.org/10.1108/C

Załęcka-Myszkiewicz, M. (2013). Unconventional building structures in single family social housing. Architecture Civil Engineering Environment, 6 (3), 31-36. Retrieved from: http://www.acee-journal.pl/

Zami, M.S. \& Lee, A. (2010). Earth as an alternative building material for sustainable low cost housing in Zimbabwe. Retrieved from http://www.irbnet.de/daten 